\title{
PERDA DO MANDATO POR INFIDELIDADE PARTIDÁRIA: REFLEXOS JURÍDICOS DA APROVAÇÃO DA PEC 113/2015 DO SENADO FEDERAL
}

\author{
LOSS OF OFFICE FOR PARTY INFIDELITY: LEGAL CONSEQUENCES OF THE \\ APPROVAL OF THE PEC 113/2015 OF THE FEDERAL SENATE
}

\author{
Priscila Wieczorek Spricigo Cadore ${ }^{1}$
}

\section{RESUMO}

O presente artigo tem como objetivo analisar os reflexos jurídicos da aprovação da Proposta de Emenda à Constituição n.113/2015 do Senado Federal, que reforma as instituições político-eleitorais no país, no que tange ao instituto da infidelidade partidária, num cenário de crise sociopolítica e econômica. Partiu-se do pressuposto de que tal aprovação, ensejando status constitucional à matéria e reiterando, quanto ao aspecto material, o conteúdo da Resolução do TSE n. 22.610/2007, que disciplina o processo de perda do cargo por infidelidade partidária e que teve sua inconstitucionalidade parcial decretada no julgamento da ADI n. 5081/2015, para torná-la inaplicável aos cargos do sistema eleitoral majoritário, poderia novamente legalizá-la, tendo em vista que as decisões no controle concentrado de constitucionalidade não obrigam o Poder Legislativo em sua função típica, bem como tornaria automática a perda do cargo, sem a necessidade de intervenção do Poder Judiciário. Para a consecução do objetivo proposto, foram realizadas pesquisas bibliográfica e documental, tendo-se como fontes produções legislativa, jurisprudencial e jornalística, em função da atualidade do tema. Concluiu-se que a redação final da emenda, de forma distinta de sua proposição inicial, dota-se de aplicabilidade imediata por sê-la definidora de direito fundamental e apresenta-se como norma constitucional de eficácia contida, podendo ser restringida em seu alcance por norma regulamentar, hoje representada pela Resolução TSE 22.610 e que, por constitucionalizar seus artigo primeiro e parágrafo primeiro, deixa assente a inaplicabilidade aos eleitos pelo sistema majoritário e a necessidade de processo judicial sob a égide do devido processo legal para a decretação da perda do cargo, situação que poderá ser alterada com a atuação do legislador ordinário. Além disso, prevê prazo de transição de inaplicabilidade da regra, enfraquecendo a autonomia partidária.

Palavras-chave: infidelidade partidária. Perda do cargo. PEC/SF n. 113/2015. Sistemas eleitorais proporcional e majoritário. Resolução TSE n. 22.610/2007.

\footnotetext{
1 Especialista em Direito Eleitoral e Processual Eleitoral pela Universidade Federal do Tocantins (UFT). Especialista em Ciências Criminais (UFT). Advogada, bacharel em Direito pela Universidade Federal do Tocantins (UFT); publicitária, graduada pelo Centro Universitário Luterano de Palmas (CEULP/ULBRA). Professora do Curso de Direito da Fundação Universidade do Tocantins (UNITINS) e conciliadora / mediadora cadastrada junto ao centro judiciário de solução consensual de conflitos do TJ/TO. E-mail: priscilaws.cadore@gmail.com.
} 


\begin{abstract}
This article aims to examine the legal consequences of the adoption of the Proposed Amendment to the Constitution n. 113 / 2015 of the Senate, to reform the political and electoral institutions in the country, regarding the Institute of party loyalty in a crisis scenario socio-political and economic. It started with the assumption that such approval, allowing for constitutional status to matter and reiterating, as regards material, the content of the TSE Resolution n. 22.610 / 2007, which regulates the position of the loss process in these conditions and had partial unconstitutionality handed down in the trial of ADI n. 5081/2015, to make it inapplicable to the positions of the majority electoral system, it could again legalize it, given that decisions on the constitutionality of concentrated control does not require the legislature in its typical function, and become automatic loss position without the need for judiciary intervention. To achieve the proposed objective, bibliographic and documentary research carried out, having as sources productions legislative, judicial and journalistic, depending on the theme today It was concluded that the final wording of the amendment , differently from its initial proposal, it possesses immediate applicability by being it defining a fundamental right and presents itself as a constitutional norm contained effectiveness and may be restricted in scope by regulatory standard, currently represented by Resolution TSE 22,610 and, by constitutionalise articles 1 and $\$ 1$, let established the inapplicability to elected by the majority system and the need for judicial process under the aegis of due process for job loss decree, a situation that can be changed by the action of the ordinary legislator. It also provides for a period of rule of inapplicability transition, weakening the party autonomy.
\end{abstract}

Key-words: party infidelity. Loss of office. PEC 113/2015 of the Federal Senate. Proportional and majority electoral systems. Resolution TSE n. 22.610 / 2007.

\title{
1 CONSIDERAÇÕES INICIAIS
}

O cenário brasileiro de crise sociopolítica e econômica, marcado por recentes movimentos populares anticorrupção, que projetam em potenciais vícios ou "brechas" legais do sistema eleitoral vigente o substrato para futuras gestões fraudulentas da coisa pública, ensejou a revitalização de projetos de mudança legislativa em trâmite há décadas no Congresso Nacional, conjugados na retomada de processo legislativo de emenda à Constituição, visando ao que se conjecturou chamar "Reforma Política".

Uma das principais pautas do debate envolve o instituto da fidelidade partidária, que preconiza o dever do eleito em candidatura efetivada por determinado partido político de manter-se nele filiado durante o exercício do mandato, sob pena 
de perda do cargo, exceto nos casos de justificação de desfiliação partidária, hoje regulados pela Resolução do Tribunal Superior Eleitoral - TSE n. 22.610/2007.

Conjugada a matéria na Proposta de Emenda à Constituição - PEC n. 113/2015 do Senado Federal, oriunda da Câmara dos Deputados - com tramitação nesta Casa sob a denominação de "PEC da fidelidade partidária", (PEC/CD n.182/2007) -, o presente artigo tem como objetivo analisar os reflexos jurídicos de sua aprovação.

Para a consecução do objetivo proposto, foram realizadas pesquisas bibliográfica e documental, tendo-se como fontes produções legislativa, jurisprudencial e jornalística, em função da atualidade do tema, servindo de fundamento para posterior ratificação ou refutação da hipótese de que a aprovação da emenda em comento, ensejando status constitucional à fidelidade partidária e reiterando, quanto ao aspecto material, o conteúdo da Resolução do TSE n. 22.610/2007, que disciplina o processo de perda do cargo nestas condições e que teve sua inconstitucionalidade parcial decretada no julgamento da ADI n. 5081/2015, para torná-la inaplicável aos cargos do sistema eleitoral majoritário, poderia novamente legalizá-la, tendo em vista que as decisões no controle concentrado de constitucionalidade não obrigam o Poder Legislativo em sua função típica, bem como tornaria automática a perda do cargo, sem a necessidade de intervenção do Poder Judiciário.

Neste sentido, o artigo se apresenta estruturado em quatro pilares de conteúdo. O primeiro deles, intitulado Fidelidade Partidária, traz em seu bojo o instituto como um todo, tratando de sua conceituação, alcance e uso terminológico na praxe jurídica, sendo finalizado com a regulamentação jurídico-legal representada pela Resolução TSE n. 22.610/2007. O tópico seguinte, Proposta de Emenda Constitucional do Senado Federal n. 113/2015, cerne do estudo em análise, faz um comparativo entre os textos original e definitivo da proposta em tramitação no Congresso Nacional, analisando a justificação exposta pelo legislador constituinte derivado em seus pareceres e os reflexos jurídicos da aprovação da PEC no que concerne à fidelidade partidária. Por fim, no item Considerações Finais, a hipótese levantada inicialmente será verificada a fim de que se chegue a sua refutação ou ratificação. 
Espera-se com o estudo, longe de determinar os limites ditos corretos de atuação legislativa ou opor mero juízo de valor sobre a proposição em tramitação, possibilitar, ao operador do direito, as bases para aprofundamento do conhecimento ora iniciado e, aos cidadãos em geral, a efetiva participação e consciência política, a fim de ensejar o aperfeiçoamento de suas formas de convivência sociopolítica, tendo em vista a oportunidade de efetivar mudanças em projeto ainda em tramitação e que demanda processo legislativo complexo e delongado, típico de uma Constituição de natureza rígida, cuja inércia demandará tempo e nova vontade política para reformas.

\section{FIDELIDADE PARTIDÁRIA}

À democracia representativa semidireta instituída pela Constituição Federal de 1988 e evidenciada no parágrafo único de seu artigo inaugural associa-se o caráter partidário da representação política, fundamentada no pluripartidarismo e na alocação dos partidos políticos entre os direitos e garantias fundamentais do cidadão.

Desta feita, erige-se a filiação partidária como condição de elegibilidade (artigo 14, §3ำ V, CF/88), de modo a ser o partido político o viabilizador da participação eleitoral do indivíduo ou, nos dizeres de Márlon Reis, "a 'correia de transmissão' entre os interesses dos grupos civicamente mobilizados e a institucionalidade estatal acessível pela via eleita" (2012, p. 153, grifo do autor).

Neste sentido, embora o cidadão possa exercer individualmente os direitos políticos, são eles detidos coletivamente e, assim, dotados de plenitude. São os partidos os canalizadores de demandas da comunidade, os fiscalizadores da atividade estatal em busca do bem comum e grandes idealizadores de políticas públicas. Portanto, sua atividade pressupõe licitude, legitimidade e também interesses coletivos.

Sendo a agremiação a via estreita para assunção ao mandato eletivo de candidato, é de se esperar a proteção legal e jurídica à vaga obtida por ela e 
exercida pessoalmente por aquele. Daí exsurge a ideia de fidelidade partidária e, com ela, a "necessidade de excluir-se do mandato aquele que, defraudando os meios institucionais que tornaram possível sua eleição, trata de mudar-se para partido diverso daquele por meio do qual alcançou o mandato eletivo" (REIS, 2012, p. 154).

Nesse sentido fora a interpretação conforme a Constituição expressada pelo Tribunal Superior Eleitoral - TSE em resposta à Consulta n. 1398, de 2007, ensejadora da Resolução n. 22.526 de mesma data, in verbis:

[...] os Partidos Políticos e as coligações conservam direito à vaga obtida pelo sistema proporcional, quando houver pedido de cancelamento de filiação ou de transferência do candidato eleito por um partido para outra legenda [...] (BRASIL, 2007).

O Pretório Excelso reiterou o entendimento deste Tribunal Superior ao julgar, em outubro de 2007, conjuntamente, os Mandados de Segurança nํs. 26.602, 26.603 e 26.604 , cujo trecho da ementa é bastante esclarecedor da matéria:

[...] 5. No Brasil, a eleição de deputados faz-se pelo sistema da representação proporcional, por lista aberta, uninominal.

No sistema que acolhe - como se dá no Brasil desde a Constituição de 1934 - a representação proporcional para a eleição de deputados e vereadores, o eleitor exerce a sua liberdade de escolha apenas entre os candidatos registrados pelo partido político, sendo eles, portanto, seguidores necessários do programa partidário de sua opção. 0 destinatário do voto é o partido político viabilizador da candidatura por ele oferecida. 0 eleito vincula-se, necessariamente, a determinado partido político e tem em seu programa e ideário o norte de sua atuação, a ele se subordinando por força de lei (art. 24, da Lei n. 9.096/95). Não pode, então, o eleito afastar-se do que suposto pelo mandante - o eleitor -, com base na legislação vigente que determina ser exclusivamente partidária a escolha por ele feita. Injurídico é o descompromisso do eleito com o partido - o que se estende ao eleitor - pela ruptura da equação político-jurídica estabelecida.

6. A fidelidade partidária é corolário lógico-jurídico necessário do sistema constitucional vigente, sem necessidade de sua expressão literal. Sem ela não há atenção aos princípios obrigatórios que informam o ordenamento constitucional.

7. A desfiliação partidária como causa do afastamento do parlamentar do cargo no qual se investira não configura, expressamente, pela Constituição, hipótese de cassação de mandato. $O$ desligamento do parlamentar do mandato, em razão da ruptura, imotivada e assumida no exercício de sua liberdade pessoal, do vínculo partidário que assumira, no sistema de representação política proporcional, provoca o desprovimento automático do cargo. A licitude da desfiliação não é 
juridicamente inconsequente, importando em sacrifício do direito pelo eleito, não sanção por ilícito, que não se dá na espécie.

8. É direito do partido político manter o número de cadeiras obtidas nas eleições proporcionais.

9. É garantido o direito à ampla defesa do parlamentar que se desfilie de partido político.

10. Razões de segurança jurídica, e que se impõem também na evolução jurisprudencial, determinam seja o cuidado novo sobre tema antigo pela jurisdição concebido como forma de certeza e não causa de sobressaltos para os cidadãos. Não tendo havido mudanças na legislação sobre o tema, tem-se reconhecido o direito de o Impetrante titularizar os mandatos por ele obtidos nas eleições de 2006, mas com modulação dos efeitos dessa decisão para que se produzam eles a partir da data da resposta do Tribunal Superior Eleitoral à Consulta n. 1.398/2007.

11. Mandado de segurança conhecido e parcialmente concedido (BRASIL, 2007c, grifo nosso).

Conforme dito, o instituto da fidelidade partidária não se assenta expressamente no ordenamento constitucional brasileiro, sendo sua aplicação jurídica fruto de interpretação sistemática e teleológica da Carta Suprema, como corolário do princípio democrático, disto resultando a perda do cargo por afronta aos seus pressupostos, como consequência jurídica de ato lícito que expressa a vontade pessoal do eleito.

Há, na hipótese, simples remissão constitucional ao tema no $\S^{0}$ do artigo 17, atribuindo aos partidos e seus estatutos o estabelecimento de normas de regência da matéria, como resultado de sua autonomia (BRASIL, 1988).

Se para alguns autores, como o magistrado Márlon Reis e o constitucionalista Eros Grau, desnecessária a legalização ou constitucionalização da matéria, posto que derivada da sistemática constitucional, o atual cenário sociopolítico de manifestações populares anticorrupção, tendo como norte a modificação do sistema eleitoral, cujo vício poderá ensejar futuras gestões fraudulentas da coisa pública pelos eleitos, trouxe ao debate a questão, por meio da Proposta de Emenda Constitucional n. 182/2007, da Câmara dos Deputados, com tramitação no Senado Federal sob o número 113/2015, seguindo processo eleitoral previsto no artigo 60, $\S 2^{\circ}$, da Constituição Federal, como será visto posteriormente.

Diante das decisões do TSE e do Supremo Tribunal Federal - STF, acima elencadas, bem como da suposta omissão legislativa sobre o assunto, editou-se a Resolução TSE n. 22.610, de 25 de outubro de 2007 (posteriormente alterada pela Resolução n. 22.733, de 11 de março de 2008), que trata do processo de perda de cargo por infidelidade partidária, objeto do próximo tópico. 
Oportuno, aqui, destacar o uso generalizado da expressão fidelidade partidária pela doutrina e jurisprudência, de modo que tanto o vínculo partidário do eleito, como a ruptura ou desfiliação após assunção ao mandato, tendo como consequência a perda do mesmo, são abordados sob a sua denominação, restando ao termo infidelidade partidária uso informal ou jornalístico, pela facilidade de compreensão de seu alcance. Como se verá, também na novel legislação, os pareceres resultantes das deliberações congressistas e mesmo as redações da proposta de emenda em comento, quando separadas por tópicos, demonstram preferência por aquela terminologia.

Diante deste contexto, por questões didáticas e de acessibilidade do leitor à bibliografia disponível, visto a maior dificuldade de busca documental acerca da matéria sob a denominação infidelidade partidária, optou-se por utilizá-la no título deste trabalho, com a ressalva de não sê-la a praxe jurídica tradicional.

\subsection{Resolução TSE n. 22.610/2007}

Não há como se falar em fidelidade partidária sem fazer remissão à Resolução n. 22.610/2007 do TSE.

Isto porque representa ela, a par de não elencar espécie normativa primária constante do artigo 59 da Constituição Federal, norma regulamentar feita pelo Tribunal Superior Eleitoral no exercício da sua competência (art. 23, XVIII, do Código Eleitoral), num contexto em que se ausenta o Poder Legislativo a respeito do tratamento dado à ruptura da fidelidade partidária.

Neste sentido, empresta-se trecho do voto do Ministro Carlos Ayres Britto, do TSE, no julgamento do Recurso em Mandado de Segurança n. 341-AgR/RS, ao abordar a constitucionalidade de outra resolução daquele tribunal:

[...] E quando tomei ciência da resolução desta egrégia Casa, entendi que ela tinha um caráter meramente expletivo, ou seja, ela não inovou primariamente a ordem jurídica; limitou-se a aplicar a Constituição de modo didático, na mesma linha decisória do Supremo Tribunal Federal. [...] (BRASIL, 2015d).

Destarte, a Resolução n. 22.610 regulamenta o processo de perda de cargo por infidelidade partidária tendo como norte a decisão, acima transcrita, do Pretório 
Excelso no julgamento conjunto dos Mandados de Segurança ํos. 26.602 a 26.604, quando se reitera a consequência jurídica prejudicial ao eleito por seu ato de desfiliação partidária, assegurando-Ihe o devido processo legal.

Ademais, define o ato contrário à fidelidade partidária ensejador da perda de cargo, até então relegado à doutrina e jurisprudência, como se vê da leitura do artigo $1^{\circ}$ e seu parágrafo inicial:

Art. 1ํ - O partido político interessado pode pedir, perante a Justiça Eleitoral, a decretação da perda de cargo eletivo em decorrência de desfiliação partidária sem justa causa.

$\S 1^{\circ}$ - Considera-se justa causa:

I) incorporação ou fusão do partido;

II) criação de novo partido;

III) mudança substancial ou desvio reiterado do programa partidário;

IV) grave discriminação pessoal (BRASIL, 2007c, grifo nosso).

Assim, pode-se considerar a infidelidade partidária, de acordo com a resolução em apreço, como sendo o ato injustificado de desfiliação partidária do mandatário, afastável apenas nas hipóteses de incorporação ou fusão do partido, criação de novo partido, mudança substancial ou desvio reiterado do programa partidário e grave discriminação pessoal.

Ainda segundo a norma regulamentar, não há perda automática do cargo, sendo legitimados, primeiramente, o partido político interessado, e, na inércia deste, o Ministério Público Eleitoral e aqueles que tiverem interesse jurídico, a formular o pedido de decretação de perda do cargo eletivo do ora desfiliado (art. $1^{\circ}, \S^{\circ} \stackrel{\circ}{ }$, Res. 22.610/TSE).

Quanto à competência, é do próprio Tribunal Superior Eleitoral o processo e julgamento, nos casos de mandato parlamentar federal, e dos respectivos Tribunais Regionais Eleitorais, para os demais casos (art. 1ํ, §4, Res. 22.610/TSE).

Pouco mais de um ano de vigência da norma, contudo, sua constitucionalidade fora posta em xeque no julgamento das Ações Diretas de Inconstitucionalidade (ADIs) 3999 e 4086, ajuizadas pelo Partido Social Cristão (PSC) e pela Procuradoria Geral da República (PGR), sob a alegação de que teria o TSE usurpado competência legislativa e violado, assim, a separação de Poderes; bem como legislado sobre direito eleitoral, direito processual e procedimental, constitucionalmente funções atribuídas à União Federal. Além disso, haveria 
hostilização ao devido processo legal com a legitimação de interessados jurídicos sobre a causa e outorga de função ao Ministério Público sem previsão na lei de regência daquela instituição (BRASIL, 2008).

Por 9 votos a 2, o Plenário do STF declarou improcedentes os pedidos de declaração de inconstitucionalidade no dia 12 de novembro de 2008, sob o argumento de que a edição da resolução seria resultado do preceito constitucional da eficácia da coisa julgada material, no caso, a decisão do Pretório Excelso de considerar inconstitucional a prática da infidelidade partidária, de modo que caberia ao TSE definir os procedimentos de atuação nos processos envolvendo a matéria (BRASIL, 2008).

A plena constitucionalidade da resolução do TSE perdurou até 27 de maio de 2015, quando do julgamento da ADI n. 5081, ajuizada pelo Procurador Geral da República, almejando a declaração de inconstitucionalidade parcial da norma, quanto às expressões "ou o vice", do artigo 10, "e, após 16 de outubro corrente, quanto a eleições pelo sistema majoritário", do artigo 13, e conferir interpretação conforme a Constituição Federal ao termo "suplente", do artigo 10. À unanimidade, os ministros aprovaram a tese de que: "A perda do mandato em razão da mudança de partido não se aplica aos candidatos eleitos pelo sistema majoritário, sob pena de violação da soberania popular e das escolhas feitas pelo eleitor" (BRASIL, 2015e).

Oportuna a transcrição da ementa desta recente decisão:

DIREITO CONSTITUCIONAL E ELEITORAL. AÇÃO DIRETA DE INCONSTITUCIONALIDADE. RESOLUÇÃO № 22.610/2007 DO TSE. INAPLICABILIDADE DA REGRA DE PERDA DO MANDATO POR INFIDELIDADE PARTIDÁRIA AO SISTEMA ELEITORAL MAJORITÁRIO. 1. Cabimento da ação. Nas ADls no 3.999/DF e 4.086/DF discutiu-se o alcance do poder regulamentar da Justiça Eleitoral e sua competência para dispor acerca da perda de mandatos eletivos. O ponto central discutido na presente ação é totalmente diverso: saber se é legítima a extensão da regra da fidelidade partidária aos candidatos eleitos pelo sistema majoritário.

2. As decisões nos Mandados de Segurança oㅡ 26.602, № 26.603 e 26.604 tiveram como pano de fundo o sistema proporcional, que é adotado para a eleição de deputados federais, estaduais e vereadores. As características do sistema proporcional, com sua ênfase nos votos obtidos pelos partidos, tornam a fidelidade partidária importante para garantir que as opções políticas feitas pelo eleitor no momento da eleição sejam minimamente preservadas. Daí a legitimidade de se decretar a perda do mandato do candidato que abandona a legenda pela qual se elegeu.

3. O sistema majoritário, adotado para a eleição de presidente, governador, prefeito e senador, tem lógica e dinâmica diversas da do sistema proporcional. As características do sistema majoritário, com sua ênfase na figura do candidato, fazem com que a perda do mandato, no caso de 
mudança de partido, frustre a vontade do eleitor e vulnere a soberania popular (CF, art. 1으, par. ún. e art. 14, caput).

4. Procedência do pedido formulado em ação direta de inconstitucionalidade (BRASIL, 2015d).

Desta feita, até a conclusão dos trabalhos do Congresso Nacional no exercício de sua competência, com vistas à regulamentação constitucional específica da matéria, a ser abordada na sequência, permanece vigente a Resolução TSE 22.610/2007, com a ressalva de não sê-la aplicável aos mandatários eleitos pelo sistema majoritário que se desfiliem sem justa causa de suas agremiações de origem.

\section{PROPOSTA DE EMENDA CONSTITUCIONAL DO SENADO FEDERAL $\mathbf{N}$. $113 / 2015$}

Cerne do presente estudo, a Proposta de Emenda Constitucional n. 113, de 19 de agosto de 2015, de autoria da Câmara dos Deputados, visa à reforma das instituições político-eleitorais, alterando os artigos 14, 17, 57 e 61 da Constituição Federal, e à criação de regras temporárias para vigorar no período de transição para o novo modelo, acrescentando o art. 101 ao Ato das Disposições Constitucionais Transitórias (BRASIL, 2007a).

A PEC em tramitação no Senado Federal, contudo, tem hoje redação final bastante distinta daquela que originariamente fora concebida pela Casa Autora, sendo imprescindível, assim, a análise de sua evolução para a compreensão do alcance e dos reflexos jurídicos de sua potencial promulgação (após aprovação, em dois turnos, na Câmara dos Deputados, a proposta já teve votação favorável do Plenário do Senado em primeiro turno, com retorno das atividades deliberativas no início de 2016, necessitando de apenas mais um turno de votação para aprovação final e promulgação conjunta pelas Mesas da Câmara e do Senado, conforme processo legislativo previsto no artigo 60 e seguintes da Constituição Federal).

A par da recente alteração constitucional em tramitação no Senado com vistas à Reforma Política, em especial à temática da fidelidade partidária, seu substrato data de 23 de outubro de 2007, quando do recebimento, na Câmara dos Deputados, da chamada PEC da Fidelidade Partidária, sob a numeração 182. 
Menos flexível e mais abrangente que a PEC 113/2015, a proposta pretendia, nas palavras do Relator da Comissão de Constituição e Justiça da Câmara, o Deputado Federal Espiridião Amim, a contenção da migração partidária, com a construção constitucional de um novo modelo democrático embasado na representatividade partidária, um desejo antigo dos parlamentares da Casa, tendo em vista representar a aglutinação das propostas de emenda constitucional sobre a matéria a ela anteriores - PECs 85, 90, 137 e 251 de 1995; 542 de 1997; 24, 27, 143 de 1999; 242 de 2000 e 124 de 2007 (BRASIL, 2011).

A perda do cargo se daria de forma automática, sem a necessidade de movimentação do Poder Judiciário, distinguindo-se do atual deslinde processual da Resolução TSE n. 22.610/2007, já abordada, e englobaria mandatários eleitos tanto pelo sistema proporcional quanto pelo majoritário, tendo-se como única causa de justificação para a desfiliação partidária a extinção, incorporação ou fusão de partido político, conforme sua redação original:

Altera os arts. 17, 46 e 55, da Constituição Federal, para assegurar aos partidos políticos a titularidade dos mandatos parlamentares e estabelecer a perda dos mandatos dos membros do Poder Legislativo e do Poder Executivo que se desfiliarem dos partidos pelos quais foram eleitos.

Art. 1‥ Os artigos 17, 46 e 55 da Constituição Federal passam a vigorar com as seguintes alterações:

"Art. 17

$[\ldots]$

V. Titularidade dos mandatos parlamentares.

[...]

§ 5o Perderá automaticamente o mandato o membro do Poder Legislativo ou do Poder Executivo que se desfiliar do partido pelo qual tenha sido eleito, salvo no caso de extinção, incorporação ou fusão do partido político.

$\S 6$ - A perda do mandato eletivo de ocupante do Poder Executivo será declarada pelo Tribunal Superior Eleitoral, quando se tratar de Presidente ou Vice-Presidente da República, pelo Tribunal Regional Eleitoral quando se tratar de Governador ou Vice-Governador de Estado ou do Distrito Federal, e pelo Juiz Eleitoral, quando se tratar de Prefeito ou Vice-Prefeito, mediante comunicação do órgão de direção partidária de respectivo nível.

$\S 7^{\circ}$ A comunicação prevista no $\S 6^{\circ}$ será acompanhada de documento comprobatório da desfiliação, observado o disposto nos artigos 79,80 e 81, desta Constituição, para os casos de Presidente ou Vice-Presidente da República, e, para os demais casos, também o disposto na respectiva Constituição Estadual ou Lei Orgânica municipal." (NR)

"Art. 46

[...]

$\S 3^{\circ}$ Cada Senador será eleito com dois suplentes do mesmo partido." (NR). "Art. 55

$[\ldots]$

VII - que se desfiliar do partido político pelo qual tenha sido eleito, salvo no caso de extinção, incorporação ou fusão. 
$[\ldots]$

$\S 5^{\circ}$ No caso previsto no inciso VII, a perda do mandato será declarada pela Mesa da Casa respectiva, no prazo máximo de três sessões ordinárias ou extraordinárias, mediante comunicação do órgão de direção nacional do partido político, acompanhada de documento comprobatório da desfiliação." (NR) (BRASIL, 2007a).

Quase uma década de tramitação e 62 emendas analisadas resultaram na redação final da PEC 182/2007, apresentada em 12 de agosto de 2015, cujo trecho acerca da fidelidade partidária coincide com o então deliberado na PEC n. 113/2015 do Senado Federal, ora transcrito:

Art. $4^{\circ} \mathrm{O}$ art. 14 da Constituição Federal passa a vigorar acrescido do seguinte $\S 12$ :

"Art. 14.

$\S 12$. O detentor de mandato eletivo que se desligar do partido pelo qual foi eleito perderá o mandato, salvo nos casos de grave discriminação pessoal, mudança substancial ou desvio reiterado do programa praticado pela agremiação e de criação, fusão ou incorporação do partido político, nos termos definidos em lei."(NR) (BRASIL, 2015c).

Comparando-se as redações original e final, verifica-se a manutenção da perda do mandato nas hipóteses de desligamento do partido, sem a especificação do tipo de mandato, se oriundo do sistema eleitoral majoritário ou proporcional, remetendo à legislação infraconstitucional o detalhamento das hipóteses de exceção. Além disso, constitucionaliza o modelo de justas causas para a desfiliação voluntária do partido já preconizado pelo Poder Judiciário por meio da Resolução TSE n. 22.610/2007 e abole a expressão perda "automática" do mandato, buscando possibilitar o direito de defesa do mandatário considerado "infiel" ao seu partido de origem (BRASIL, 2015a).

Por fim, uma das alterações mais criticadas pela imprensa quanto à PEC 113/2015 e já aprovada pelo Senado Federal, em apartado do texto principal e nos dois turnos de votação e, portanto, somente à espera de sua promulgação, envolve as regras de transição da Reforma Política entoada, qual seja, a denominada "janela partidária”. Observa-se que as demais matérias destacadas, entre elas a que trata da infidelidade partidária, seguem tramitação, autuadas como PEC 113-A, de 2015, junto à Comissão de Constituição e Justiça do daquela Casa. 
Segundo tal janela, por um período de trinta dias - observa-se que na proposta aprovada pela Câmara Federal ostentava a mesma cento e oitenta dias -, contados da promulgação da Emenda Constitucional, os detentores de mandato eletivo poderão se desligar do partido pelo qual foram eleitos, sem prejuízo para seus respectivos mandatos, não sendo computado tal ato em relação à distribuição dos recursos do Fundo Partidário e ao acesso gratuito ao tempo de rádio e televisão.

Se para os congressistas a medida "é importante para a necessária acomodação das forças políticas em face de uma Reforma Política profunda como a que ora se propõe" (BRASIL, 2015a), para os críticos ela enfraquece os partidos políticos, afrontando uma necessidade política vital para o país no momento (REFORMA..., 2015).

Diante de todo o exposto, questiona-se acerca do verdadeiro alcance da constitucionalidade da infidelidade partidária trazida pela proposta em tramitação, tendo em vista a generalidade do tratamento da matéria em sua redação final e a remissão expressa a legislação infraconstitucional para sua regulação específica após um longo período de omissão legislativa, que não parece findar com a aprovação da PEC, isto porque, quando da menção dos pareceres deliberativos da proposta a comissões criadas com a finalidade de viabilizar normas infraconstitucionais reguladoras, não se inclui regras de fidelidade partidária.

Neste contexto, muitas são as repercussões advindas da reforma política ora intentada, com a única certeza de que quaisquer falhas no processo legislativo, sejam elas de natureza formal ou material, deverão ter sua solução dada pelo Poder Judiciário, seja pelo seu pioneirismo e exclusividade na regulamentação da matéria objeto de estudo, seja pela proposição de novas respostas para a pacificação dos conflitos que possam ser por elas gerados no meio social, daí a necessidade de se analisar nesta oportunidade a proposta e ensejar as mudanças necessárias, visando à harmonia dos Poderes do Estado.

\section{CONSIDERAÇÕES FINAIS}

A Reforma Política tem ganhado no país status de necessidade primária, sendo vislumbrada socialmente como uma das mais eficazes soluções para a problemática da corrupção, sob o argumento de que um processo eleitoral viciado 
favorece o exercício de mandatos eletivos ímprobos, com desvios e pouco equânimes.

Neste sentido, a infidelidade partidária, ao transformar-se em vantagem competitiva para agremiações desconexas com o preceito democrático e as demandas sociais, serve de moeda de troca visando a benefícios legais no processo eleitoral e também se reflete no desvirtuamento da vontade popular, sendo imprescindível o tratamento legislativo reformador a propiciar maior segurança jurídica e social para o cidadão e sua representatividade político-partidária.

O estudo aqui realizado teve como ponto de partida a verificação da hipótese de que a aprovação da PEC da Fidelidade Partidária (PEC SF 113/2015), ensejando status constitucional à matéria e reiterando, quanto ao aspecto material, o conteúdo da Resolução do TSE n. 22.610/2007, que disciplina o processo de perda do cargo nestas condições e que teve sua inconstitucionalidade parcial decretada no julgamento da ADI n. 5081/2015, para torná-la inaplicável aos cargos do sistema eleitoral majoritário, poderia novamente legalizá-la neste ponto, tendo em vista que as decisões no controle concentrado de constitucionalidade não obrigam o Poder Legislativo em sua função típica, bem como tornaria automática a perda do cargo, sem a necessidade de intervenção do Poder Judiciário.

Ocorre que tal hipótese confirmar-se-ia sem maiores embates se a emenda em questão tivesse mantido sua redação original, expressamente aplicável aos mandatários eleitos dos Poderes Legislativo e Executivo e, portanto, envolvendo qualquer sistema eleitoral, seja ele proporcional ou majoritário, e ainda prevendo a perda automática do cargo, a ser declarada pelo órgão competente do Poder Judiciário.

Com as emendas apresentadas e aprovadas nas deliberações da proposta já na tramitação na Câmara dos Deputados, excluiu-se, porém, as expressões "automaticamente" e "membros do Poder Legislativo e do Poder Executivo", alterando muito pouco sobre a matéria, em especial no campo material, tendo em vista a reprodução da regulamentação infraconstitucional vigente, qual seja o disposto nos artigos $1^{\circ}$ e $\S^{1} \stackrel{0}{ }$ da Resolução TSE n. 22.610/2007, que define infidelidade partidária e as causas de justificação para permanência no cargo.

Por outro lado, na seara formal encontra-se o maior legado da constitucionalização do instituto, visto tratar-se de norma constitucional definidora de 
direito fundamental que possui aplicabilidade imediata, conforme previsão do artigo $5^{\circ}$, $\S^{1^{\circ}}$, da CF, e detentora de eficácia jurídica negativa e positiva; aquela, obrigando o legislador infraconstitucional a compatibilizar-se em sua função típica legiferante e transformando-se em parâmetro para o controle de constitucionalidade; esta, servindo de parâmetro para se interpretar a Constituição.

O fato de optar o legislador constitucional por dotar a norma constitucional de eficácia contida ou plena restringível não the retira o aspecto regulamentar e sua aplicabilidade imediata, apenas possibilita ao legislador ordinário a restrição desse direito. Nesse ponto, em não havendo pronunciamento legislativo infraconstitucional vigente, parece revigorar-se o procedimento previsto na resolução do TSE, haja vista a declaração de sua constitucionalidade pela Corte Suprema e, com ela, a inaplicabilidade do dispositivo constitucional aos mandatários eleitos pelo sistema majoritário, como Senadores e Chefes do Poder Executivo.

Neste aspecto, a generalidade com que fora tratado o tema e a remissão a norma legal reguladora, dotada de processo legislativo mais célere e menos rígido que o previsto constitucionalmente para emendar-se a Constituição, deixa latente a possibilidade de que venham a ser os cargos obtidos via sistema eleitoral majoritário também incidentes da norma, a depender da vontade do legislador ordinário.

Isto porque, não estando o Poder Legislativo obrigado pelas decisões proferidas pelo STF em sede de controle concentrado de constitucionalidade, não há impedimento para que a lei em sentido estrito que venha a regulamentar a matéria amplie a incidência das consequências jurídicas da infidelidade partidária aos mandatários dos Poderes Executivo e Legislativo, conforme redação originária da PEC em comento, restando ao STF pronunciar-se especificamente sobre a nova norma legal.

Importante destacar, aqui, que o Pretório Excelso também não está adstrito as suas decisões em sede de controle de constitucionalidade, sob pena de engessamento do órgão (FERNANDES, 2014), de modo que um novo posicionamento quanto à perda de cargo por infidelidade partidária para eleitos sob o sistema majoritário poderá ser manifestado, modificando profundamente a incidência do disposto via emenda em tramitação.

Na redação aprovada pela Câmara dos Deputados e em votação no Senado, a falta de previsão explícita na Constituição Federal de perda do mandato no caso 
de infidelidade partidária para cargos do sistema majoritário, ante a interpretação de afronta ao primado da soberania popular, conforme emanado pela Corte Suprema, e a manutenção da Resolução TSE n. 22.610 como única regulação da matéria, levanos ao entendimento pela perseverança da inaplicabilidade a tais casos.

De qualquer forma, a fim de garantir maior segurança jurídica e social a representantes e representados no sistema eleitoral, seria mais producente ao legislador constitucional derivado a definição do alcance da norma constitucional, deixando à lei ordinária apenas a definição do procedimento para decretação da perda do cargo, o que demonstra certa incoerência jurídica fruto da celeridade com que tem sido engendrada a Reforma Politica.

Incoerência esta que ganha contornos ainda maiores quando se trata da chamada "Janela Partidária", regra de transição a prever prazo para inaplicabilidade da perda do cargo por infidelidade partidária a qualquer mandatário, seja ele englobado ou não pelas excludentes ou causas justificadoras, o que representa verdadeiro subterfúgio dos criadores e propensos destinatários da norma para seu descumprimento, já que não se trata de inovação no ordenamento jurídico, mas de constitucionalização de instituto já vigente, de modo a ser facilmente desqualificada a tese exposta pelos parlamentares de que uma Reforma Política tão abrangente necessitaria de um prazo para acomodação das forças políticas.

\section{REFERÊNCIAS}

BRASIL. Câmara dos Deputados. Parecer à Proposta de Emenda à Constituição n. 182/2007. Brasília: Câmara dos Deputados (Comissão de Constituição e Justiça), 2011. Disponível

em:<http://www2.camara.leg.br/proposicoesWeb/prop_mostrarintegra?codteor=8960 04\&filename=PRL+1+CCJC+\%3D\%3E+PEC+182/2007>. Acesso em: 30 de jan. 2016.

. Câmara dos Deputados. Parecer à Proposta de Emenda à Constituição n. 182/2007. Brasília: Câmara dos Deputados (Comissão Especial da Reforma Política), 2015a. Disponível em:< http://www2.camara.leg.br/proposicoesWeb/prop_mostrarintegra?codteor $=1332561 \&$ filename $=P R L+1+P E C 18207+\% 3 D \% 3 E+P E C+182 / 2007>$. Acesso em: 30 de jan. 2016. 
- Câmara dos Deputados. Proposta de Emenda à Constituição n. 182/2007. Brasília: Câmara dos Deputados, 2007a. Disponível em:<http://www2.camara.leg.br/proposicoesWeb/prop mostrarintegra;jsessionid=85 3D8E1F70EDF7E83012872714097D9D.proposicoesWeb1 ?codteor $=516056 \&$ filenam e=PEC+182/2007>. Acesso em: 30 de jan. 2016.

Constituição Federal. Brasília: Senado Federal, 1988. Disponível em:<http://www.senado.gov.br/atividade/const/con1988/con1988_08.09.2016/ind.asp >. Acesso em: 10 de dez. 2016.

. Senado Federal. Parecer $\mathrm{n}^{\circ}$ 1.166, de 9 de dezembro de 2015. Brasília: Senado Federal, 2015b. Disponível em:< http://www.senado.leg.br/atividade/rotinas/materia/getPDF.asp?t=184925\&tp=1 >. Acesso em: 30 de jan. 2016.

. Senado Federal. Proposta de Emenda à Constituição n. 113, de 19 de agosto de 2015. Brasília: Senado Federal, 2015c. Disponível em:<file:///C:/Users/Dunya\%20e\%20Marcelo/Downloads/sf-sistema-sedol2-iddocumento-composto-43361\%20(1).pdf>. Acesso em: 30 de jan. 2016.

. Supremo Tribunal Federal. Acordão de decisão que declarou a inaplicabilidade da regra de perda do mandato por infidelidade partidária ao sistema eleitoral majoritário. Ação Direta de Inconstitucionalidade n. 5.081. Requerente: Procurador-Geral da República; Interessado: Tribunal Superior Eleitoral. Relator: Ministro Luís Roberto Barroso. Brasília-DF, 25 maio de 2015d. Disponível em:<www.stf.jus.br/arquivo/cms/noticiaNoticiaStf/anexo/ADI5081 .pdf>. Acesso em: 30 de jan. 2016.

. Supremo Tribunal Federal. Natureza jurídica e efeitos da decisão do Tribunal Superior Eleitoral - TSE na Consulta n. 1.398/2007. Mandados de Segurança nํ․ 26.602, 26.603 e 26.604. Partido dos Democratas e Presidente da Câmara dos Deputados. Relator: Ministro Eros Grau. Brasília-DF, 4 out. 2007c. Disponível em:<http://webcache.googleusercontent.com/search?q=cache:3bQHNFHm8YJ:www.stf.jus.br/portal/processo/verProcessoTexto.asp\%3Fid\%3D2233920 \%26tipoApp\%3DRTF+\&cd=1\&hl=pt-BR\&ct=clnk\&gl=br>. Acesso em: 1 fev. 2016.

. Supremo Tribunal Federal. Perda do mandato por troca de partido não se aplica a eleições majoritárias. Brasília-DF, 27 maio 2015e. Disponível1em:<http://www.stf.jus.br/portal/cms/verNoticiaDetalhe.asp?idConteudo= 292424>. Acesso em: 30 de jan. 2016.

Supremo Tribunal Federal. STF confirma constitucionalidade de Resolução do TSE sobre fidelidade partidária. Brasília-DF, 12 nov. 2008. Disponível1em:<http://www.stf.jus.br/portal/cms/verNoticiaDetalhe.asp?idConteudo= 98954>. Acesso em: 23 out. 2015.

Tribunal Superior Eleitoral. Resolução n. 22.526, de 8 de maio de 2007 (Consulta n. 1398/2007). Consulta, eleições proporcionais, candidato eleito, cancelamento de filiação, transferência de partido, vaga, agremiação. Consulente: 
Partido da Frente Liberal. Relator: Ministro Cesar Asfor Rocha. Brasília-DF, 2007b. Disponível em:< file:///C:/Users/Dunya\%20e\%20Marcelo/Downloads/tse-resolucao22526-consulta-no-1398.pdf>. Acesso em: 01 fev. 2016.

Tribunal Superior Eleitoral. Resolução n. 22.610, de 25 de outubro de 2007. Disciplina o processo de perda de cargo eletivo, bem como de justificação de desfiliação partidária. Relator: Ministro Cezar Peluso. Brasília-DF, 2007c. Disponível em:<http://www.tse.jus.br/internet/partidos/fidelidade_partidaria/res22610.pdf>. Acesso em: 01 fev. 2016.

FERNANDES, Bernardo Gonçalves. Curso de Direito Constitucional. 6. ed. rev., atual., e ampl. Salvador-BA: JusPodivm, 2014.

REIS, Márlon. Direito Eleitoral Brasileiro. Brasília-DF: Alumnus, 2012.

REFORMA de Cunha estimula infidelidade partidária. O Globo (online), Rio de Janeiro, 23 jun. 2015. Disponível em:<http://oglobo.globo.com/opiniao/reforma-decunha-estimula-infidelidade-partidaria-16522179>. Acesso em: 30 jan. 2016. 